\title{
Ženske \\ v izobraževanju odraslih
}

Vera Kozmik

\begin{abstract}
Pekinška platforma namenja izobraževanju posebno poglavje, $v$ katerem zahteva od držav, vlad in vseh odgovornih vpeljavo mehanizmov, ki bi ženskam omogočili izobraževanje skozi vsa obdobja njihovega življenja in s tem izboljšali njegovo kakovost.
\end{abstract}

Modernizacijski tokovi so nas v zadnjih nekaj desetletjih pripeljali do stopnje, ko brez permanentnega izobraževanja v (post)moderni družbi ni več mogoče preživeti. Če je pri konstituiranju moderne dobe veljala pismenost za prvi pogoj bivanja $\mathrm{v}$ moderni družbi, organiziranje množičnega izobraževanja pa jo je omogočalo, ta dandanes še zdaleč ne zagotavlja več uspešnega funkcioniranja. In če je posamezniku v petdesetih, šestdesetih letih srednješolska izobrazba še zagotavljala neke vrste »varnost « in ni bilo sistemske potrebe po posebnem dodatnem poklicnem izobraževanju, nam dandanes že laičen premislek in osebna izkušnja povesta, da prosti čas, prej namenjen konjičkom, vse bolj »razjeda« potreba po permanentnem poklicnem izobraževanju kot načinu »boja za preživetje $\ll$.

Vse te zahteve seveda ne nastajajo na način »sui generis«. Podane so in se realizirajo $\mathrm{v}$ posebnih družbenih, zgodovinskih okvirih in razmerah, hkrati pa se spreminjajo. Še posebno to velja za Slovenijo, ki v zadnjih letih doživlja korenite socialne spremembe, s prehodom iz socialističnega političnega in ekonomskega sistema v kapitalističnega. Učinki prehoda so pozitivni in negativni, kar gotovo čutimo vsi. Seveda se učinki prehoda kažejo tudi na vseh drugih področjih, v sistemih, politiki itd. Tudi pri andragoškem izobraževanju, pri katerem bi lahko govorili o dveh tipih pomembnih procesov. Gre za procese diskontinuitete in kontinuitete. Prvi pomenijo prelomnice, ki se dogajajo pri prehodu v kapitalistični sistem, drugi pa vzorce, ki so se obdržali tudi v tranziciji.

Glede položaja žensk v zvezi z izobraževanjem lahko v procesih kontinuitete opazimo naslednje: $v$ socializmu je bilo pri nas zaposlenih veliko žensk, za večino je bilo povsem normalno, da jim je bilo šolanje omogočeno, da so ga dokončale in da so se zaposlile. Če ne upoštevamo funkcionalnih razlogov, ki jih je država imela za vsiljevanje zaposlovanja žensk (predvsem gre tu za potrebo po delovni sili zato, da bi bila sploh mogoča industrializacija), lahko danes ugotovimo, da je to naša prednost pred ženskami v zahodnoevropskih državah. Hkrati je bila država naklonjena permanentnemu izobraževanju, kar je razvidno iz celega kompleksa institucij, ki so omogočale različne vrste izobraževanja (delavske univerze, sindikati, večerne šole). Ves sistem je bil seveda funkcionalno načrtovan, predvsem pa se je dopolnjeval z različnimi ideološkimi pedagoškimi koncepti, kot je bil na primer koncept VRO - vsestransko razvite osebnosti. Toda bil je sistem in treba bi bilo ohraniti tisto, kar je bilo najboljše v njem. Seveda pa ga ne bi bilo treba samo ohraniti, temveč tudi uporabiti in obogatiti.

Kljub pozitivnim vidikom množičnega izobraževanja in tudi zaposlovanja žensk v preteklosti pa se ob natančnejšem premisleku pokaže tudi marsikatera slaba stran. Razlog zaposlovanja očit- no ni bila večja enakopravnost žensk z moško polovico prebivalstva, temveč omenjena potreba po delovni sili in formalna zavezanost ženski emancipaciji. Posledica, prosim, da mi dovolite te poenostavitve, tega je bila, da je bila v sferi zaposlovanja izvedena enakopravnost, v zasebni sferi pa je položaj ostajal nespremenjen, strogo tradicionalen, patriarhalen in konservativen. Prva, zelo jasna, posledica resničnosti, ki ji skoraj nihče ne ugovarja, je seveda dvojna obremenjenost žensk: obremenjenost z obveznostmi v službi in doma. Na drugi strani pa so posledice tudi veliko globlje: formalna enakopravnost je oblikovala družbeno krinko, ki je onemogočala žensko gibanje, ki bi prinašalo prepotrebne spremembe v vrednote, mišljenje in čutenje družbe, posebej pa še žensk. Spolna delitev dela se je torej v družini še naprej ohranjala, hkrati pa se je tudi podvojila v javni sferi, s čimer so se nekateri poklici povsem feminizirali.

Pojav je seveda precej kompleksen. Najprej prihaja v nasprotje $\mathrm{z}$ omenjeno aktivno politiko permanentnega izobraževanja. Opisan položaj povzroča protiučinke, saj preobremenjene ženske niso zmogle še dodatnega bremena permanentnega izobraževanja oziroma so bile njihove notranje aspiracije po dodatnem izobraževanju zaradi obremenjenosti z obveznostmi precej majhne. Eden od rezultatov reproduciranja spolne delitve dela in podvojitve tega vzorca $\mathrm{v}$ sferi zaposlovanja je na primer tudi sedanja struktura pozicij, ki kaže, da so na vodilnih mestih predvsem moški. Iz povedanega lahko sklepamo, da se v preteklosti na ženske aktivno spodbujanje permanentnega izobraževanja sploh ni nanašalo, saj so bile te preveč zaposlene z drugimi obveznostmi, povezanimi z materinstvom in družino na splošno.

Seveda moj namen ni kriviti socializma za vse, kar je storil, in za položaj, v katerem trenutno smo, temveč orisati in izostriti razmere, v katerih smo trenutno ženske. Te pa oblikujejo tudi procesi diskontinuitete, ki pomenijo »vnose « sprememb, ki so bodisi izvirne bodisi (in to največkrat) prenesene iz drugih družb - v našem primeru iz zahodnoevropskih. Nove razmere so položaj žensk še zaostrile, če je to sploh še mogoče, saj od njih zahtevajo maksimalno aktivnost v zasebni in javni sferi, hkrati pa so postale zahteve po vedno višji izobrazbi ter permanentnemu izobraževanju večje. To je navsezadnje razvidno tudi iz statistike vpisovanja na šesto in sedmo stopnjo izobraževanja, kamor se vpisuje vedno več mladih. Takoj pa je treba dodati, da tudi ta izobrazba ne zadostuje več - vedno več diplomantov se namreč odloča tudi za podiplomski študij. Tu se ženska polovica prebivalstva spet pojavi v posebnem položaju. Obdobje študija je tudi obdobje, ko se največ žensk odloča za materinstvo (povprečna starost matere ob rojstvu prvega otroka je bila v letu 1993 24,6 let). Materinstvo se tako vedno bolj kaže kot tista »ovira«, ki lahko žensko v njenem poklicnem življenju močno omejuje, 


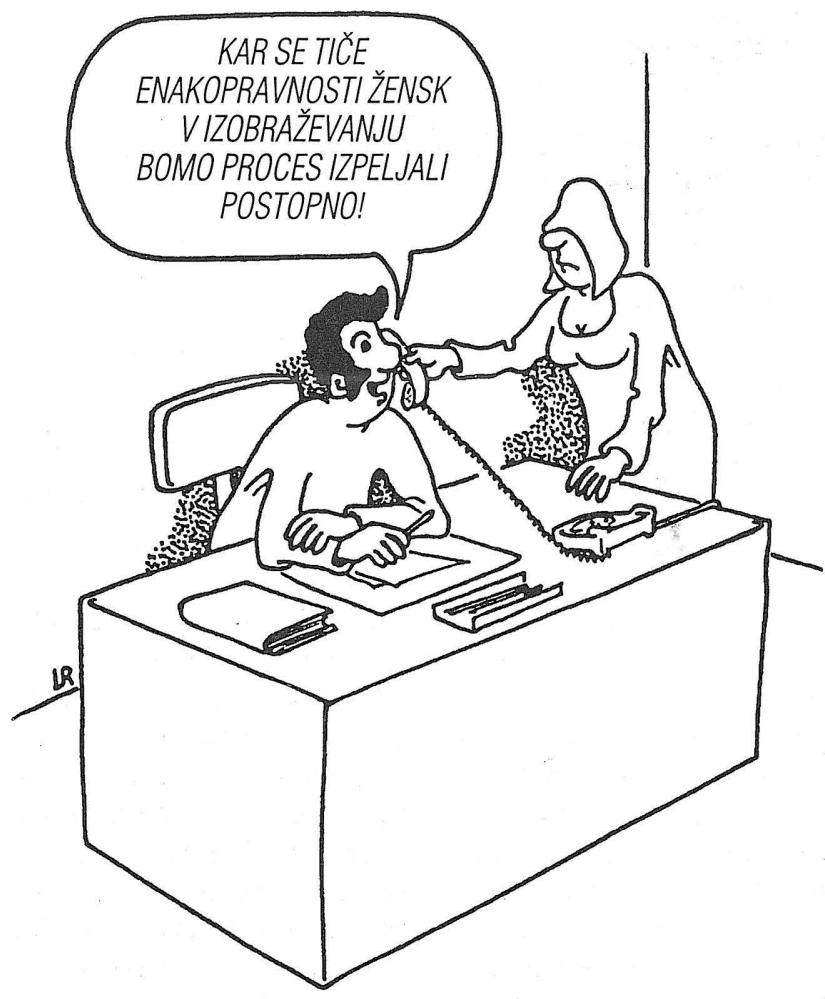

saj že ob vstopu na trg delovne sile težko ugodi zahtevam, ki jih poklicno delo postavlja, ne meneč se za njene zasebne obveznosti. Posebej poudarjam »materinstvo« in posebej »ovire«. Če govorimo namreč samo o materinstvu, in ne tudi o očetovstvu, potem moramo $\mathrm{v}$ moderni družbi to nujno povezati tudi $\mathrm{z} \gg$ ovirami«. Prav bi bilo, da se zamislimo nad temi našimi stereotipnimi koncepcijami in začnemo poudarjati individualnost pravic in odgovornosti tudi v zvezi s starševstvom. Sicer nam dobri programi in zamisli o rednem izobraževanju, povezani z vseživljenskim izobraževanjem, nikoli ne bodo dali takšnih rezultatov, kot jih najbrž načrtujemo, temveč nam bodo razlike in nemožnosti samo še povečevali. Pri tem se namreč ujamemo na klasičnem »kavlju«, govorjenju o izbiri kot najvišji vrednoti in pridobitvi za posameznika, posameznico, s poznavanjem osnov te izbire pa se pokaže, da izbire pravzaprav ni. Govoriti o izbirah, kadar nimamo vsi enakih možnosti, osnov, navsezadnje tudi politične volje družbe in države, je čista ideologija. Med te osnovne možnosti, zahteve spada seveda tudi permanentno izobraževanje, saj brez njega, kot je bilo že rečeno, ne more nihče enakopravno tekmovati $\mathrm{z}$ drugimi sodelavkami in sodelavci in velikih besed o prosti izbiri je kaj hitro konec.

Problem seveda ni samo naš, mirno lahko rečemo, da je to problem celega sveta, kar je razvidno tudi iz postavljenih zahtev in ciljev, oblikovanih $\mathrm{v}$ dokumentu svetovne konference OZN o ženskah, tako imenovani pekinški platformi. Ta namreč izobraževanju namenja posebno poglavje, v njem pa predvsem zahteva vpeljavo mehanizmov in veliko odgovornost držav, vlad in vseh, ki bodo ženskam omogočali izobraževanje skozi vse življenje in s tem izboljšanje kakovosti njihovega življenja.

Razmere pri nas tudi v tem trenutku niso idealne, zato se tudi pri nas postavljajo zahteve po izboljšanju mehanizmov za izobraževanje skozi vse življenjsko obdobje, za moške in ženske. Spremembe pa se morajo začeti že pri sistemu izobraževanja mladih.

Predvsem je treba zagotoviti enak dostop do izobraževanja, čeprav se zdi, da je pri nas to že zagotovljeno. Tu kaže še enkrat poudariti primer mladih mater, ki bi jim morali omogočiti, da se enakopravno vključijo v študij ali pa ga uspešno dokončajo. Zagotoviti bi bilo treba tudi spodbujanje žensk, da se odločijo za podiplomski študij, saj je osip žensk zaradi posebne reproduktivne funkcije največji ravno tu.

Ženske z nizko stopnjo izobrazbe bi morali spodbujati, da bi se odločale za nadaljnje šolanje, ker si lahko le po tej poti izboljšajo ali pa sploh zagotovijo neodvisno ekonomsko eksistenco. V tem smislu bi morali narediti tudi več zato, da bi zmanjšali spolno segregacijo poklicev, ki so zgolj transformacija »zaželenih« ženskih vlog v družini - na primer terapevtska, vzgojna vloga (varuške, vzgojiteljice, učiteljice ipd.) in gospodinjska opravila (kuharice, čistilke, frizerke ipd.).

Država bo morala zagotoviti mehanizme neformalnega izobraževanja v obliki raznih tečajev, seminarjev. Ne moremo sicer reči, da teh pri nas primanjkuje, takoj pa lahko dodamo, da so ti po navadi precej dragi in si jih lahko privoščijo le tisti z višjimi osebnimi dohodki. Nimam sicer podatkov in analiz, sem pa skoraj prepričana, da bi se hipoteza, da je v izobraževanju, ki ga plačujejo podjetja, v zadnjem času manj žensk in da je struktura te populacije precej drugačna, kot je bilo to pred leti, potrdila. Manjka nam oblik izobraževanja, ki bi bilo vsaj delno subvencionirano. Na tem mestu velja dodati, da izobraževanje na splošno, sočasno s tem, ko znanje in informacije postajajo najpomembnejši kulturni kapital, postaja stvar ugleda, ki ga je treba plačati. To velja ne le za omenjene tečaje, temveč tudi za dodiplomski in podiplomski študij.

Zelo radi pozabljamo na cel spekter skupin žensk, ki jih označujemo kot marginalne skupine, med njimi so invalidke, begunke, imigrantke, upokojenke. Tudi tu je marsikaj že storjenega, na primer upokojenke in upokojenci se lahko vključijo v izobraževanje na tretji univerzi, ki je sicer dobro programsko zastavljena, žal pa premalo poznana, predvsem pa geografsko nerazpršena.

Posebna skupina, ki se s problemom brezposelnosti izrazito povečuje, so brezposelne ženske. Ne samo tiste, ki prvič stopajo na trg delovne sile, temveč predvsem tiste, ki so zaposlitev v obdobju tranzicije izgubile. Te bi morali bolj spodbujati k vključevanju v različne izobraževalne programe in jim to tudi omogočiti. Ta skupina je namreč še posebno izpostavljena, saj obstaja nevarnost, da bodo zaradi dolgotrajne brezposelnosti te ženske ostale doma, se prelevile $\mathrm{v}$ gospodinje in opustile misel na ponovno zaposlitev.

Verjetno bi primere potrebnih ukrepov glede izobraževanja na splošno, in še posebej andragoškega izobraževanja, še lahko naštevala, kar pa ni moj namen, saj andragoški delavci sami najbolje poznate razmere in možnosti za ukrepanje.

Vera Kozmik

direktorica Urada za žensko politiko 